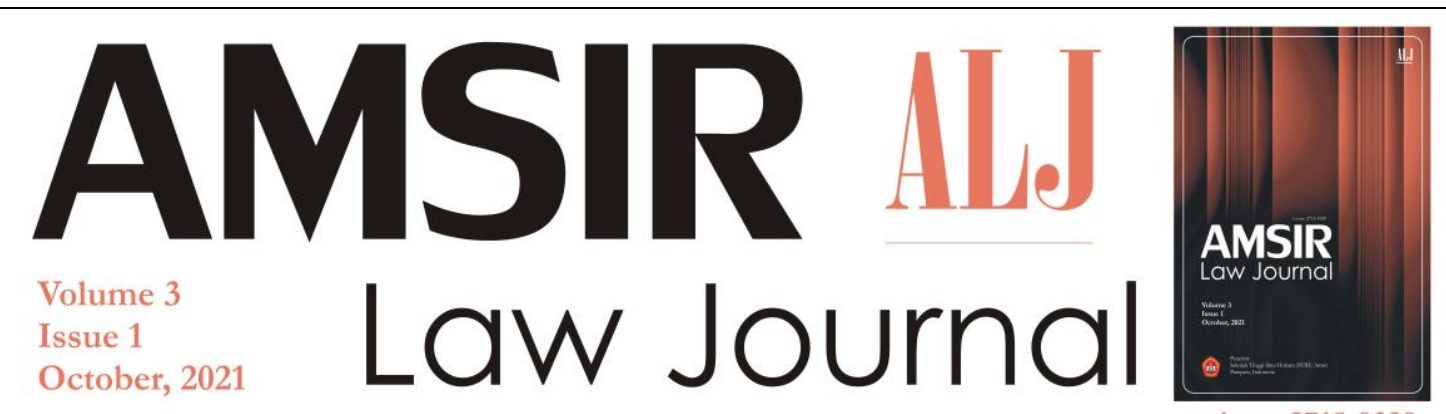

This work is licensed under a Creative Commons Attribution 4.0 International License.

\title{
Hakikat Ketentuan Transisional dalam Pembentukan Peraturan Perundang-undangan
}

\author{
Alwiyah Sakti Ramdhon Syah Rakia ${ }^{1}$, Kristi Warista Simanjuntak ${ }^{2}$, \\ Wahab Aznul Hidaya ${ }^{3}$, Andi Darmawansya ${ }^{4}$.
}

\section{ARTICLE INFO}

Keywords:

Ketentuan Peralihan; Aturan

Peralihan; Peraturan Perundang-

undangan.

How to cite:

Rakia, Alwiyah Sakti

Ramdhon Syah.,

Simanjuntak, Kristi Warista.,

Hidaya, Wahab Aznul.,

Darmawansya, Andi. (2021).

Hakikat Ketentuan

Transisional dalam

Pembentukan Peraturan

Perundang-undangan. Amsir

Law Journal, 3(1), 30-38.

DOI:

10.36746/alj.v3i1.44

\section{ABSTRACT}

In the process of drafting regulations, transitional provisions are used in order to overcome the legal vacuum, legal certainty, legal protection, and regulate other matters of a transitional nature. In terms of nomenclature, transitional provisions are referred to by different terms but are considered to have the same meaning. However, the terms of the transitional provisions have certain differences. This study aims to answer the nature of the transitional provisions in every formation of legislation, as well as the status of meaning between the terms "Ketentuan Peralihan" and "Aturan Peralihan" which have the same meaning status in the system of forming legislations. The results of this study indicate that the preparation of the "Transitional Provisions" material in the Appendix to Law Number 15 of 2019 is not adequately used in the preparation of "Aturan Peralihan" in the constitution. This is because the essence of the preparation of transitional provisions in the constitution is not only in order to overcome the legal vacuum, legal certainty, legal protection, and regulate other matters of a transitional nature, but also because of the transfer of power.

\section{Pendahuluan}

Dalam Pasal 1 Undang-undang Nomor 12 tahun 2011 tentang Pembentukan Peraturan Perundang-undangan, sebagaimana telah diubah dengan Undang-undang Nomor 15 Tahun 2019 tentang Perubahan Atas Undang-undang Nomor 12 Tahun 2011 tentang Pembentukan Peraturan Perundang-undangan (UU P3) diterangkan bahwa pembentukan peraturan perundang-undangan adalah pembuatan peraturan perundang-undangan yang mencakup tahapan perencanaan, penyusunan, pembahasan, pengesahan atau penetapan,

${ }^{1}$ Fakultas Hukum, Universitas Mubammadiyah Sorong, Sorong, Indonesia. E-mail: saktialwiyah@um-sorong.ac.id

${ }^{2}$ Fakultas Hukum, Universitas Muhammadiyah Sorong, Sorong, Indonesia.E-mail: kristiwarista98@ogmail.com

${ }^{3}$ Fakultas Hukum, Universitas Mubammadiyah Sorong, Sorong, Indonesia. E-mail: wahabaznulbidaya@,um-sorong.ac.id

${ }^{4}$ Fakultas Hukum, Universitas Muslim Indonesia, Makassar, Indonesia. E-mail: darmawansya.andi@gmail.com 
pengundangan. Dengan kata lain, apabila pembentukan peraturan tidak melalui tahapan ini maka pembentukan suatu peraturan dianggap tidak legitimate. Walaupun demikian, harus diakui dalam praktik tidak semua pembentukan peraturan melalui tahapan tersebut. ${ }^{5}$

Pembentukan Peraturan Perundang-undangan dilakukan dalam rangka mencukupi kebutuhan hukum nasional demi terselenggaranya keadilan dan kepastian hukum yang bermartabat sebagai cerminan dari konsep negara hukum. Artinya setiap materi muatan yang hendak disusun dalam rancangan peraturan sedapat mungkin mengakomodir materimateri yang dianggap penting agar tidak terjadi kekosongan hukum (rechtsvacuum). Sekalipun demikian, secara alamiah suatu peraturan tidak selalu dapat mengakomodir seluruh materi hukum, terlebih lagi manakala suatu peraturan yang dibentuk ternyata berkaitan dengan peraturan-peraturan lain. Oleh sebab itu, biasanya dalam suatu peraturan diatur juga mengenai suatu ketentuan yang bersifat transisional dengan tujuan untuk mengatasi kekosongan hukum.

Ketentuan transisional dalam UU P3 disebut dengan "Ketentuan Peralihan" sebagai definisi operasional bagi ketentuan yang bersifat penyesuaian atau mengatur hubunganhubungan hukum. Dalam Undang-Undang Dasar Negara Republik Indosnesia (UUD NRI) 1945, ketentuan transisional disebut dengan "Aturan Peralihan”. Sedangkan dalam Naskah Komprehensif Perubahan UUD NRI 1945, justru disebut lagi dengan isitilah lain yaitu istilah "Ketentuan Aturan Peralihan". Sejauh ini istilah "Ketentuan Peralihan" dan "Aturan Peralihan" dianggap memiliki makna yang sama. Namun secara operasional kedua istilah ini cukup menimbulkan kebingungan, karena dalam UU P3 tidak ada keterangan bahwa "Aturan Peralihan" memiliki status dan makna yang sama dengan "Ketentuan Peralihan".

Dalam proses penyusunan materi hukum, keberadaan ketentuan yang bersifat transisional memang diperlukan sebagai upaya untuk menjamin kepastian hukum. Akan tetapi, ada perbedaan mengenai penyusunan ketentuan transisi antara konstitusi dan peraturan perundang-undangan lainnya. Penyusunan ketentuan transisi dalam pembentukan konstitusi umunya menggunakan dua mekanisme, yaitu interim constitutions dan transitional provisions. ${ }^{7}$ Interim constitutions berkaitan dengan proses perancangan konstitusi, pembatasan sementara, serta penyediaan kerangka kerja dalam membangun kepercayaan politik antara berbagai kelompok kepentingan yang terlibat dalam proses tersebut. Sedangkan, transitional provisions pada dasarnya merupakan ketentuan sementara yang secara jelas menguraikan urutan dan waktu transisi. ${ }^{8}$

Proses penyusunan ketentuan transisional dalam konstitusi agak sedikit berbeda dengan penyusunan ketentuan transisional dalam peraturan perundangan lainnya. Hal ini disebabkan karena penyusunan ketentuan transisional dalam konstitusi biasa terjadi peralihan kekuasaan politik. Maka dari itu, apabila unsur-unsur ketentuan transisional sebagaimana disebutkan dalam Lampiran II UU P3 yang menyangkut dengan "Ketentuan Peralihan", dapat dilihat bahwa tujuan dari penyusunan "Ketentuan Peralihan" tidak

\footnotetext{
${ }^{5}$ Misalnya pembentukan peraturan Peraturan Pemerintah Pengganti Undang-undang (Perpu/Perppu) yang tidak selalu melalui tahapan perencanaan.

6 Tim Penyusun Naskah Komprehensif Proses dan Hasil Perubahan UUD 1945. (2010). Naskah Komprehensif Perubahan Undang-Undang Dasar Negara Republik. Indonesia Tabun 1945: Latar Belakang, Proses, dan Hasil Pembahasan, 1999-2002, Buku X Perubahan UUD, Aturan Peralihan, dan Aturan Tambahan. Jakarta: Sekretariat Jenderal dan Kepaniteraan Mahkamah Konstitusi, hlm. 169.

7 Alston, E., \& Ginsburg, T. (2017). Playing for Constitutional Time: Interim Constitutions \& Transitional Provisions. Ginsburg, Tom, and Eric Alston." Playing for constitutional time: Interim constitutions and transitional provisions." The Timing of Lawmaking (2017), 110.

${ }^{8}$ Ibid.
} 
memasukkan unsur peralihan kekuasaan politik. Namun, apakah hal ini berpengaruh pada perbedaan istilah yang digunakan, belum ada penjelasan yang tegas mengenai ini.

Pada hakikatnya, konstitusi dapat diubah kapan saja sepanjang memenuhi syarat Pasal 37 UUD NRI 1945. Namun apabila dalam proses amandemen konstitusi diperlukan penyusunan ketentuan transisi, apakah proses penyusunannya bergantung pada Lampiran II UU P3, atau dengan sarana hukum lainnya yang ditetapkan pada saat amandemen akan dilakukan. Penelitian ini bemaksud menjawab dua pertanyaan, yaitu: bagaimana hakikat ketentuan transisional dalam setiap pembentukan peraturan perundang-undangan? Dan apakah istilah "Ketentutan Peralihan" dan "Aturan Peralihan" memiliki status makna yang sama dalam sistem pembentukan peraturan perundang-undangan?

\section{Metode}

Tipe penelitian dalam penulisan ini adalah penelitian hukum normatif-yuridis dengan pendekatan kualitatif. Sifat penelitian ini adalah preskriptif-analitis, yakni metode yang dipakai untuk menggambarkan suatu kondisi atau keadaan yang sedang terjadi atau berlangsung yang tujuannya agar dapat memberi data seteliti mungkin mengenai obyek penelitian sehingga mampu menggali hal-hal yang bersifat ideal, kemudian dianalisis berdasarkan teori hukum yang relevan dengan obyek penelitian. Jenis bahan hukum yang digunakan dalam penelitian ini adalah bahan hukum primer, bahan hukum sekunder, serta bahan hukum tersier. Bahan hukum Primer terdiri dari peraturan perundang-undangan. Bahan hukum sekunder terdiri dari teori hukum sesuai dengan objek masalah yang diteliti. Bahan hukum tersier terdiri dari surat kabar online maupun offline, kamus hukum, dan sebagainya, untuk menunjang informasi dan istilah yang digunakan dalam penelitian.

\section{Hakikat Ketentuan Transisional dalam Pembentukan Peraturan Perundang- undangan}

Dalam sistem pembentukan peraturan perundang-undangan di Indonesia dikenal dua istilah berbeda untuk menyebutkan peraturan transisi, yaitu "Aturan Peralihan" dan "Ketentuan Peralihan". Istilah "Aturan Peralihan" hanya digunakan pada UUD NRI 1945, namun jarang digunakan atau tidak digunakan sama sekali pada undang-undang biasa. Sedangkan istilah "Ketentuan Peralihan" lazim digunakan di sejumlah peraturan perundang-undangan kecuali UUD NRI 1945. Meski terdapat perbedaan istilah, nampaknya istilah "Aturan Peralihan" dan "Ketentuan Peralihan" dianggap memiliki makna yang sama, yakni sebuah aturan atau ketentuan yang fungsi utamanya untuk mencegah terjadinya kekosongan hukum pada masa transisi.

Walaupun dianggap memiliki makna yang sama, perbedaan istilah antara "Aturan Peralihan" dan "Ketentuan Peralihan" cenderung membingungkan untuk digunakan secara operasional. Dalam Lampiran II UU P3, definisi operasional tentang "Ketentuan Peralihan" diuraikan secara konseptual-fungsional. Akan tetapi tidak ada penjelasan apakah hal tersebut juga berlaku bagi istilah "Aturan Peralihan". Dalam Naskah Komprehensif Perubahan UUD NRI 1945, justru disebut lagi dengan istilah lain yaitu istilah "Ketentuan Aturan Peralihan", yang terjadi karena pencampuran antara ketentuan dalam Aturan Peralihan dan Aturan Tambahan. ${ }^{9}$

Kalau diperhatikan, istilah "Aturan Peralihan" merupakan istilah asli yang hanya digunakan UUD 1945 sejak disahkan pada tanggal 18 Agustus 1945. Selanjutnya pada Konstitusi Republik Indonesia Serikat, ${ }^{10}$ ketentuan transisional diistilahkan dengan

\footnotetext{
9 Tim Penyusun Naskah Komprehensif Proses dan Hasil Perubahan UUD 1945. (2010). Op.Cit.

${ }^{10}$ Keputusan Pres. RIS 31 Djan. 1950 Nr. 48.(c) LN 50-3.
} 
"Ketentuan-Ketentuan Peralihan", yang juga digunakan dalam UUDS 1950. Pada saat diberlakukan kembali UUD NRI 1945 hingga amandemen 1999-2002, istilah "Aturan Peralihan" dipertahankan hingga sekarang, namun materi muatannya mengalami perubahan.

Sebelum amandemen, Aturan Peralihan UUD NRI 1945 berjumlah IV (empat) butir, sedangkan sesudah amandemen Aturan Peralihan UUD NRI 1945 berjumlah III (tiga) butir. Perbedaan materi muatan Aturan Peralihan UUD NRI 1945 sebelum dan sesudah amandemen mencirikan keadaan dan kebutuhan zaman masa itu. Namun yang pasti, ketentuan transisional pada UUD NRI 1945 baik sebelum atau sesudah amandemen bukan dengan tujuan untuk mengatasi kekosongan hukum semata, namun juga disebabkan adanya peralihan kekuasaan.

Ketentuan peralihan merupakan sebuah ketentuan dalam peraturan perundangundangan yang rumusannya dapat didefinisikan ketika diperlukan atau jika diperlukan, yang berarti tidak semua peraturan perundang-undangan mempunyai ketentuan peralihan. ${ }^{11}$ Dalam Lampiran II UU P3, dijelaskan bahwa "Ketentuan Peralihan" memuat penyesuaian pengaturan tindakan hukum atau hubungan hukum yang sudah ada berdasarkan peraturan perundang-undangan yang lama terhadap peraturan perundang-undangan yang baru, yang bertujuan untuk:

1) Menghindari terjadinya kekosongan hukum;

2) Menjamin kepastian hukum;

3) Memberikan perlindungan hukum bagi pihak yang terkena dampak perubahan ketentuan Peraturan Perundang-undangan; dan

4) mengatur hal-hal yang bersifat transisional atau bersifat sementara.

Kalau diperhatikan, pada dasarnya "Ketentuan Peralihan" bersifat fakultatif, dalam arti bukan merupakan suatu kewajiban dalam kerangka atau sistematika peraturan perundang-undangan, yakni disusun apabila dibutuhkan. Dalam Lampiran UU P3, Ketentuan Peralihan dituangkan ke dalam bab tersendiri, di antara "Ketentuan Pidana" (jika diperlukan) dan "Ketentuan Penutup". Apabila dalam suatu perundang-undangan tidak diadakan pengelompokan bab, dalam arti hanya terdiri dari pasal-pasal, maka pasal yang memuat "Ketentuan Peralihan" dapat ditempatkan sebelum pasal atau beberapa pasal sebelum "Ketentuan Penutup".

Penyusunan "Ketentuan Peralihan" juga dapat memuat ketentuan mengenai penyimpangan sementara atau penundaan sementara, bagi tindakan atau hubungan hukum tertentu. Sebagai contoh, dapat dilihat Pasal 99A UU P3 Perubahan yang mana "pada saat pembentukan kementerian atau lembaga yang menyelenggarakan urusan pemerintahan di bidang pembentukan peraturan perundang-undangan belum terbentuk, tugas dan fungsi pembentukan peraturan perundang-undangan tetap dilaksanakan oleh menteri yang menyelenggarakan urusan pemerintahan di bidang hukum." Begitupun pada Pasal 27 Undang-undang Nomor 39 Tahun 2008 tentang Kementerian Negara yang mana "Kementerian yang sudah ada pada saat berlakunya undang-undang ini tetap menjalankan tugasnya sampai dengan terbentuknya kementerian berdasarkan ketentuan dalam undangundang ini."

Selain penyimpangan sementara tersebut, penyusunan Ketentuan Peralihan juga dapat disusun dengan memuat penyimpangan terhadap ketentuan perundang-undangan yang diberlaku-surutkan. Apabila suatu peraturan perundang-undangan diberlakukan surut, maka

${ }^{11}$ Hariningsih, S. (2018). Ketentuan Peralihan Dalam Peraturan Perundang-Undangan. Jurnal Legislasi Indonesia, 6(4), 595602. 
peraturan tersebut hendaknya memuat ketentuan yang berkaitan dengan status dari tindakan atau hubungan hukum yang terjadi, dalam tenggang waktu berlaku surutnya suatu peraturan perundang-undangan dan kapan mulai berlakunya. Contoh: "Selisih tunjangan perbaikan yang timbul akibat Peraturan Pemerintah ini dibayarkan paling lambat 3 (tiga) bulan sejak saat tanggal pengundangan Peraturan Pemerintah ini."

Hal-hal lain yang berkaitan dengan kaidah penyusunan "Ketentuan Peralihan", yakni penundaan sementara bagi tindakan atau hubungan hukum tertentu. Misalnya, jika ada suatu ketentuan dalam suatu peraturan perundang-undangan yang menunda sementara berkaitan dengan tindakan atau hubungan hukum tertentu, maka tindakan atau hubungan hukum yang mengalami penundaan sementara tersebut harus dimuat secara tegas dan rinci, serta jangka waktu penghentiannya. Sebagai contoh: "Izin ekspor rotan setengah jadi yang telah dikeluarkan berdasarkan ketentuan dalam Peraturan Pemerintah Nomor ... Tahun ... tentang... masih tetap berlaku untuk jangka waktu paling lama 60 (enam puluh) hari terhitung sejak tanggal pengundangan Peraturan Pemerintah ini." Meskipun "Ketentuan Peralihan" dapat memuat materi penyimpangan atau penundaan sementara bagi tindakan atau hubungan hukum tertentu, namun penyusunan "Ketentuan Peralihan" tidak dapat memuat perubahan terselubung atas ketentuan perundang-undang lainnya.

Dalam setiap proses pembentukan peraturan perundang-undangan, ketentuan transisional memiliki manfaat yang signifikan untuk menjaga agar pelaksanaan dan penegakan hukum memiliki legitimasi. Meskipun istilah untuk menyebut ketentuan transisional berbeda-beda, namun secara substansial memiliki fungsi yang identik, yakni sebagai sarana dalam mengatasi kekosongan hukum. Hal mana dapat disebut sebagai suatu bentuk keadaan kosong atau ketiadaan peraturan perundang-undangan hukum yang mengatur tata tertib (tertentu) dalam masyarakat. ${ }^{12}$ Walaupun sebenarnya keadaan ketiadaan peraturan perundang-undangan hukum itu tidak benar-benar ada, ${ }^{13}$ karena perkembangan ilmu hukum melahirkan terobosan-terobosan dan alternatif hukum yang baru dan sesuai kebutuhan, misalnya seperti diskresi.

Manfaat dari ketentuan transisional juga bertujuan untuk menjamin kepastian hukum yang merupakan salah satu tujuan yang ingin dicapai oleh hukum. Prinsip kepastian hukum mensyaratkan bahwa aturan hukum harus diketahui, jelas, tepat, stabil, pasti dan dapat diprediksi. ${ }^{14}$ Penyusunan ketentuan transisional dalam proses pembentukan peraturan dimaksudkan agar apabila suatu materi tidak diatur dalam peraturan yang telah dibentuk, maka terhadap peristiwa hukum lainnya dapat merujuk pada aturan-aturan yang disebutkan dalam ketentuan transisi. Namun disini terkadang timbul masalah yang berkaitan dengan ketentuan transisional, ketika aturan yang dirujuk oleh ketentuan transisi juga sebenarnya bukan aturan yang tidak memadai. Dengan kata lain, kepastian hukum bukan beban persoalan yang ada pada ketentuan-ketentuan transisional, melainkan problem legislasi yang lamban.

Sebenarnya, masalah kepastian hukum bukan persoalan apakah hukumnya ada atau tidak, tetapi bisa dijelaskan atau tidak. Prinsip "kepastian hukum" bukanlah ilmu hukum dogmatik tetapi merupakan kajian dalam teori hukum yang sedikit banyak harus dideskripsikan melalui pendekatan teoretis. Prinsip kepastian hukum dalam peraturan perundang-undangan memang merupakan gagasan yang problematis dan dapat

12 Pratama, F. S. (2019). Rechtsvacuum Phenomenon in Government Regulation of the Republic of Indonesia Number 51 of 2020 related to Passport Renewal Period to 10 Years. Journal of Law and Border Protection, 1(1), 51-58.

13 Rakia, A. S. R S. (2020). Perundang-Undangan Indonesia: Kajian Mengenai Ilmu dan Teori Perundang-Undangan serta Pembentukannya. CV. Social Politic Genius (SIGn).

${ }^{14}$ Van Meerbeeck, J. (2016). The Principle of Legal Certainty in the Case Law of the European Court of Justice: From Certainty to Trust. European Law Review, 41, 275. 
diperdebatkan. Sedikitnya ada tiga pandangan mengenai kepastian hukum, yakni: kepastian hukum yang berkaitan dengan perundang-undangan; kepastian hukum yang berkaitan dengan pandangan awam; dan kepastian hukum dalam pandangan hukum ortodoks. ${ }^{15}$ Dalam pada itu, dikatakan bahwa pandangan hukum ortodoks adalah pandangan yang lebih disukai dalam arti deskriptif. ${ }^{16}$ Pendapat ini juga didukung oleh penelitian lain yang menjelaskan bahwa kepastian hukum harus diuraikan dengan argumentasi hukum pada gagasan prosedural dan rasional, dengan menghubungkan antara kompleksitas hukum dengan cita hukum fundamental lainnya. ${ }^{17}$

Ketentuan transisional juga dapat memberikan suatu perlindungan hukum bagi pihakpihak yang terkena dampak-dampak atas perubahan ketentuan dalam suatu Peraturan perundang-undangan. Tentu saja hal ini dapat dilakukan ketika persoalan kekosongan hukum dan kepastian hukum telah teratasi terlebih dahulu. Walaupun perlindungan hukum kadang dipandang sebagai sesuatu yang klise, namun perlindungan hukum merupakan sebuah hak yang harus diberikan pada setiap orang. Perlindungan hukum diberikan pada setiap orang agar masyarakat dapat menikmati segala hak yang diberikan oleh hukum. ${ }^{18}$ Dengan kata lain, perlindungan hukum merupakan upaya yang harus disediakan oleh aparat penegak hukum untuk memberikan rasa aman, baik batin maupun jasmani, dari gangguan atau berbagai ancaman dari pihak manapun.

Tujuan dari penyusunan ketentuan transisional pada hakikatnya sangat baik, terlebih lagi sasaran dari penyusuanan ketentuan transisi pada peraturan perundang-undangan berdampak langsung pada warga negara. Walaupun demikian, tidak semua peraturan perundang-undangan memerlukan ketentuan-ketentuan transisi karena dalam perkembangan hukum lahir beberapa alternatif hukum yang dapat digunakan untuk memberikan hak dan kewajiban pada setiap warga negara. Suatu peraturan yang tidak memiliki ketentuan transisional namun dalam praktiknya ditemukan ketidakjelasan, dalam hal ini pengadilan yang harus diberikan beban dalam menarik kesimpulan. ${ }^{19}$ Ketentuan transisional kadang menjadi sebuah dilema hukum, yakni di satu sisi keberadaannya diperlukan untuk mengatasi problem-problem masa peralihan, namun di sisi lain hal ini juga menunjukan lemahnya kegiatan legislasi.

\section{Status Makna antara Ketentuan Peralihan dan Aturan Peralihan dalam Sistem Pembentukan Peraturan Perundang-undangan}

Sistem pembentukan peraturan perundang-undangan di Indonesia merujuk pada Pasal 5 dan Pasal 20A ayat (1) UUD NRI 1945, UU P3, serta Peraturan Presiden Nomor 87 Tahun 2014. Pengaturan mengenai ketentuan transisional dalam Lampiran II UU P3 diisitilahkan sebagai "Ketentuan Peralihan", yang penyusunannya dalam rangka mengatasi kekosongan hukum, memberikan kepastian hukum dan perlindungan hukum, serta mengatur hal-hal yang bersifat transisi. Namun tidak dijelaskan apakah hal ini juga berlaku bagi konstitusi atau hanya berlaku bagi perundang-undangan di bawah UUD NRI 1945.

Disebutkan dalam lampiran UU P3, "Ketentuan Peralihan memuat penyesuaian pengaturan tindakan hukum atau hubungan hukum yang sudah ada berdasarkan peraturan perundang-undangan yang lama terhadap peraturan perundang-undangan yang baru."

15 Barnes, J. (2008). Sources of doubt and the quest for legal certainty. Legisprudence, 2(2), 119-154.

${ }^{16}$ Ibid.

${ }^{17}$ Bertea, S. (2008). Towards a new paradigm of legal certainty. Legisprudence, 2(1), 25-45.

18 Yuliartini, N. P. R., \& Mangku, D. G. S. (2020). Legal Protection for Women Victims of Trafficking in Indonesia in an International Human Rights Perspective. International Journal of Criminology and Sociology, 9, 1397-1404.

19 Bennion, F. A. R. Transitional provisions and the Cohen question. In Understanding Common Law Legislation. Oxford University Press. 
Dalam proses pembentukan peraturan, masalah utama yang dihadapi adalah bagaimana mengaitkan sejumlah aturan yang terkena dampak dari pembentukan aturan baru. Hal ini sangat penting karena apabila ketentuan-ketentuan transisional tidak disusun secara sistematis maka akan mempengaruhi otoritas dari hukum itu sendiri. ${ }^{20}$ Oleh sebab itu pembentuk peraturan harus memberikan keseimbangan yang memadai untuk kepentingan politik, stabilitas hukum, keadilan sosial dan kepentingan publik dalam membuat ketentuan transisi.

Perbedaan antara istilah "Ketentuan Peralihan" dan "Aturan Peralihan" dipandang tidak memiliki masalah serius karena dianggap memiliki arti yang sama. Namun nampaknya tidak sesederhana itu, karena di samping istilah yang berbeda, ketentuan transisional yang dirumuskan dalam konstitusi secara khusus juga mengatur mengenai peralihan kekuasaan. Dalam Lampiran UU P3 yang mejelaskan mengenai "Ketentuan Peralihan", peralihan kekuasaan bukanlah merupakan unsur atau tujuan yang berkaitan dengan penyusunan "Ketentuan Peralihan". Kalaupun frasa "mengatur hal-hal yang bersifat transisional atau bersifat sementara" dalam Lampiran II UU P3 dimaknai pula peralihan kekuasaan, tetapi frasa ini masih ambigu.

Istilah "Ketentuan Peralihan" dan/atau "Aturan Peralihan" cukup mengalami kendala penerjemahan. Dalam glosari yang diterbitkan oleh Ikatan Penerjemah Pemerintah Indonesia (IPPI), "Ketentuan Peralihan" dalam bahasa inggris disebut dengan "transitional provisions". ${ }^{21}$ Ketika dalam proses membahas bab "Ketentuan Aturan Peralihan" pada amandemen UUD NRI 1945, I Dewa Gede Palguna menyebut istilah "transitional law" berfungsi agar tidak terjadi kevakuman hukum. ${ }^{22}$ Jimly Asshiddiqie menyebut istilah "concluding and transisional profetion" dan istilah "transitional profetion" dalam praktik penyusunan konstitusi di Rusia, yang apabila dimasukkan, maka tidak lagi memerlukan bab "Ketentuan Penutup" karena telah disatukan dalam bab ketentuan peralihan. ${ }^{23}$ Sekarang ini, dalam peraturan perundang-undangan yang berlaku di Indonesia, ketentuan transisional ditulis dengan "Ketentuan Peralihan" sesuai lampiran II UU P3, serta "Aturan Peralihan" yang digunakan dalam UUD NRI 1945.

Sekiranya UUD NRI 1945 mengalami amandemen, apakah pengaturan mengenai ketentuan transisi pada amandemen konstitusi harus didasarkan pada Lampiran II UU P3? ataukah terdapat mekanisme lain dalam membubuhkan nomenklatur ketentuan transisi pada UUD NRI 1945? Ketentuan Peralihan sebagaimana disebutkan dalam lampiran II UU P3 pada dasarnya cukup memadai dalam fungsinya sebagai sarana mengatasi kekosongan hukum, kepastian hukum, perlindungan hukum, serta pengaturan terhadap hal-hal transisi. Namun perlu diingat bahwa ketentuan transisi dalam pembentukan konstitusi juga disebabkan adanya peralihan kekuasaan. Oleh sebab itu, pada pembentukan konstitusi ada 2 (dua) hal yang diperhatikan mengingat sifat dari amandemen itu sendiri, yakni interim constitutions dan transitional provisions. ${ }^{24}$ Oleh sebab itu, "Ketentuan Peralihan" dalam Lampiran II UU P3 tidak memadai untuk menyusun materi peralihan dalam konstitusi.

Dalam pandangan Sumit Bisarya, konstitusi disusun dalam keadaan interregnum, ${ }^{25}$ sehingga penyusunan ketentuan transisional pada konstitusi menyangkut tiga langkah dan

\footnotetext{
${ }^{20}$ Deng-feng, Y. A. N. G. (2009). A Talking about the Legal Transitional Provisions, and Its Making Principle and Methods. In Legal Forum.

${ }^{21}$ Ikatan Penerjemah Pemerintah Indonesia https://penerjemahpemerintah.id/index.php/Ippi/glosari/

22 Tim Penyusun Naskah Komprehensif Proses dan Hasil Perubahan UUD 1945. (2010). Op.Cit. hlm. 185.

23 Ibid.

24 Alston, E., \& Ginsburg, T. (2017). Op.Cit.

25 Ginsburg, T. \& Huq, A. (ed). (2016). Assessing Constitutional Performance. New York: Cambridge University Press, hlm. 203-205.
} 
permasalahan. Pertama, transitional provisions provide a threshold bundle of steps set forth by a constitution in the process of institutional development. Kedua, establishment of the fundamental building blocks of the new constitutional order." Ketiga, "transitional provisions may vary to a certain extent as to their ends". ${ }^{26}$ Lebih lanjut, dikatakan bahwa ketentuan transisional dalam penyusunan konstitusi betujuan untuk mencapai dua hal, yaitu, "set up the institutions of the new constitutional order" dan "provide a legal and political framework for governance while those institutions are being established". ${ }^{27}$ Apabila pendapat ini diikuti, jelas bahwa materi penyusunan ketentuan peralihan dalam Lampiran II UU P3 belum memadai dalam mengatur hal-hal transisional yang berkaitan dengan pembentukan konstitusi.

\section{Kesimpulan}

Ketentuan Peralihan sebagaimana tertuang dalam Lampiran UU P3 tidak cukup memadai dalam hal penyusunan ketentuan-ketentuan transisional terhadap konstitusi. Hal ini disebabkan karena materi-materi yang dapat disusun sebagai aturan transisi dalam Lampiran UU P3 terbatas pada tujuan mengatasi kekosongan hukum, kepastian hukum, perlindungan hukum, serta mengatur hal-hal yang bersifat transisi. Adapun penyusunan aturan transisi dalam pembentukan konstitusi atau Undang-Undang Dasar tidak hanya dilatarbelangi oleh materi lampiran UU P3, tetapi juga karena adanya peralihan kekuasaan.

\section{Referensi}

Books with an Author:

A. S. R. S. Rakia. (2020). Perundang-Undangan Indonesia: Kajian Mengenai Ilmu dan Teori Perundang-Undangan serta Pembentukannya. CV. Social Politic Genius (SIGn).

F. A. R. Bennion. Transitional provisions and the Cohen question. In Understanding Common Law Legislation. Oxford University Press.

T. Ginsburg dan A. Huq (ed.). (2016). Assessing Constitutional Performance. New York: Cambridge University Press, p. 203-205.

Tim Penyusun Naskah Komprehensif Proses dan Hasil Perubahan UUD 1945. (2010). Naskah Komprehensif Perubahan Undang-Undang Dasar Negara Republik Indonesia Tabun 1945: Latar Belakang, Proses, dan Hasil Pembahasan, 1999-2002, Buku X Perubahan UUD, Aturan Peralihan, dan Aturan Tambahan. Jakarta: Sekretariat Jenderal dan Kepaniteraan Mahkamah Konstitusi.

Journal articles:

E. Alston, dan T. Ginsburg. (2017). Playing for Constitutional Time: Interim Constitutions \& Transitional Provisions. Ginsburg, Tom, and Eric Alston." Playing for constitutional time: Interim constitutions and transitional provisions." The Timing of Lawmaking (2017), 110.

F. S. Pratama. (2019). Rechtsvacuum Phenomenon in Government Regulation of the Republic of Indonesia Number 51 of 2020 related to Passport Renewal Period to 10 Years. Journal of Law and Border Protection, 1(1), 51-58.

J. Barnes. (2008). Sources of doubt and the quest for legal certainty. Legisprudence, 2(2), 119-154. 
J. van Meerbeeck. (2016). The Principle of Legal Certainty in the Case Law of the European Court of Justice: From Certainty to Trust. European Law Review, 41, 275.

N. P. R. Yuliartini., dan D. G. S. Mangku. (2020). Legal Protection for Women Victims of Trafficking in Indonesia in an International Human Rights Perspective. International Journal of Criminology and Sociology, 9, 1397-1404.

S. Hariningsih. (2018). Ketentuan Peralihan Dalam Peraturan PerundangUndangan. Jurnal Legislasi Indonesia, 6(4), 595-602.

S. Bertea. (2008). Towards a new paradigm of legal certainty. Legisprudence, 2(1), 25-45.

Y. A. N. G. Deng-feng. (2009). A Talking about the Legal Transitional Provisions, and Its Making Principle and Methods. In Legal Forum.

World Wide Web:

Ikatan Penerjemah Pemerintah Indonesia. Glosari Bidang Hukum dan Peraturan Perundang-Undangan. https://penerjemahpemerintah.id/index.php/Ippi/glosari/

\section{Conflict of Interest Statement:}

The author declares that the research was conducted in the absence of any commercial or financial relationships that could be construed as a potential conflict of interest.

Copyright (C) 2021 ALJ. All rightsreserved. 